\title{
Yeni Tarihselci Söylem Işığında Bir Disiplin Olarak Edebiyat
}

\author{
Literature As a Discipline in the Light of New Historicism
}

\section{Gökçen Kara Erdemir*}

\begin{abstract}
Özet
1980'li yıllarda Stephen Greenblatt'ın önderliğinde edebiyat incelemelerine yeni bir bakış açısı getirilmiştir. Bu yeni bakış açısına göre tarih geleneksel anlayışların dışında bir yaklaşımla yeniden değerlendirmeye tâbi tutulmalıdır. Yeni tarihselcilik olarak bilinen bu yeni yaklaşıma göre tarih, edebiyat ile yakın ilişkiler içerisindedir. Edebi bir metnin yazıldığı dönemi yansıttığını düşünen önceki tarihsel teorilerin aksine yeni tarihselcilik edebi bir metnin üretildiği tarihsel koşullardan ne kadar etkilendiği üzerinde durur. Aynı zamanda bu kuram o dönemin sosyal atmosferi ve yazarın psikolojik durumunu da dikkate alır. Yeni tarihselcilikte edebiyat tarihe kaynaklık edebilecek bir kanıttır. Yeni tarihselcilik temelde yazınsal eserlerin önemini vurgulayıp yazınsal olmayanı görmezden gelen geleneksel tarihi anlayışlara bir tepki olarak ortaya çıkmıştır. $\mathrm{Bu}$ kuram tarihi eleştirel bir yaklaşımla inceleyerek onun sorunsallığını vurgulamıştır; İlginçtir ki tarihsel bir yaklaşım olarak ortaya çıksa da sadece tarihi değil pek çok oluşumu ilgilendirir. Yeni tarihselcilik en çok kültür ve toplumla ilgilenmiştir. Örneğin tarihteki bir olayı ele alırken bu olayın sebeplerini o
\end{abstract}

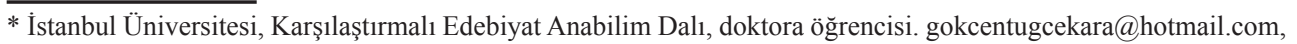


dönemin şartlarını göz önünde bulundurarak açıklamaya çalışmıştır. Yeni tarihselcilik genelde geleneksel tarihin ihmal ettiği kadınlar, ezilenler, deliler, eşcinseller gibi azınlık grupların üzerinde durur. Bu çalışmada edebiyat incelemelerinde önemli bir yeri olan yeni tarihselcilik tanıtılmıştır.

Anahtar sözcükler: yeni tarihselcilik, edebiyat, kültür, güç ilişkileri, tarih

\begin{abstract}
In the 1980s, a new perspective was introduced to the study of literature under the leadership of Stephen Greenblatt. According to this new point of view, history should be evaluated with a non-traditional approach, known as new historicism, with history in close relation with literature. Contrary to previous historical theories, which reflect the belief that a literary text reflects the period in which it was written, new historicism focuses on the influence of the historical conditions in which the literary text is produced. At the same time, this theory also takes into account the social atmosphere of the time and the psychological state of the author. Literature is evidence for history in new historicism. New historicism has emerged as a reaction to traditional historical understandings, which emphasize the importance of literary works and ignore non-literary works. This theory emphasizes the problematic nature of history by examining it with a critical approach; interestingly, although it emerges as a historical approach, it is not only about history, but about many things. New historicism is mostly interested in culture and society. For example, while addressing an event in history, this theory tries to explain the causes of this event, taking into account the conditions of that period. New historicism usually focuses on minority groups such as women, the oppressed, the insane, and homosexuals, which traditional history often ignores. This study introduces new historicism, which has an important place in literary studies.
\end{abstract}

Keywords: new historicism, literature, culture, power relations, history

\title{
Giriş
}

Tarih yirminci yüzyılda akademik ve düşünsel yapılanma içerisinde yeniden şekillenmiş, bu çerçevede sorgulamaya ve eleştiriye açık bir hale gelmiştir. Claude LeviStrauss'dan Roland Barthes'a, Sartre'a, Michael Foucault'ya kadar pek çok düşünür tarihi yeniden gözden geçirmiş, bunun sonucunda tarihin nesnel olmadığı ve politik oluşumların etkisinde kaldığı sonucuna vararak tarihsel anlatılara olan inançlarını yitirmişlerdir. Tarihi sorgulayıp kuramsal çerçevede sorunsallaştıran, onun konumunu epistemolojik ve metodolojik olarak kurumsallaştıran, diğer bir deyişle tarihe diyalektik yaklaşım getiren eleştirel kuram "yeni tarihselcilik" adını almıştır. Daha genel bir ifadeyle bu kuram, tarihi olayların tekrar edilemezliğine, her tarihsel dönemin, o döneme ait fikir ve prensipler aracılığıyla yorumlanması gerektiğini, geçmişin bugüne ait inanç, prensip ve 
motif gibi değerler çerçevesinde bilinemeyeceğini gündeme taşımıştır.

Yeni tarihselcilik kuramı ilk olarak Amerikalı eleştirmen Stephen Greenblatt tarafından 1892 yılında bir roman okuma yöntemi olarak ortaya atılmıştır. Greenblatt'a göre edebi bir eser hem tarihsel hem de metinsel bağlamı ile değerlendirilmelidir çünkü edebi bir metin üretildiği tarihsel koşullardan ve yazarın durumundan etkilenir. Diğer bir deyişle edebiyat eserleri yazıldıkları dönemin ürünleridir. O dönemin tarihsel, siyasal, kültürel ve toplumsal koşullarından etkilenir. Yeni tarihselcilik temelde tarihi anlatıların yazınsal boyutunu sorunsallaştıran bir kuramdır. Bu kuram evrensel niteliklerde kabul edilebilecek bir doğru olmadığını öne sürer. Lois Tyson'ın Critical Theory Today: A User Friendly Guide başlıklı eserinde belirttiği gibi: “Eğer Naziler II. Dünya Savaşını kazanmış olsalardı, bu savaş tarih kitaplarında çok daha farklı bir şekilde yazılacaktı. Bu yüzden yeni tarihselcilik tarihi belgeleri, yazan kişinin bakış açısına göre kaçınılmaz bir şekilde taraflı hikâyeler olarak görür" (2006:186). Tyson'un bu görüşüne göre tarafsız yazılmış tarih yoktur. İnsan zihninden çıkan her üründe kurgu vardır. Nitekim, yeni tarihselcilik kuramı da bu noktaya dikkat çekerek tarihi anlatıların kaçınılmaz bir biçimde insan eğilimlerinin sonucunda oluştuğunu gündeme taşır.

Geçmiş yaşantılar ve önemli olaylar sadece kültürel aktarımla bize ulaşmıştır. Farklı bir deyişle, geçmişten günümüze ulaşan tarihsel bilgi insan yolu ile bize aktarılmıştır. Oysa yeni tarihselci eleştirmenler insan kavramını hiçbir zaman nesnel bulmaz. Yeni tarihselcilere göre insan zihninden çıkan her şey kurmacalardan oluşur. Bu yaklaşım, tarihi olay ve anlatıların öyküsel boyutunu açığa çıkararak nesnel boyutunu sorunsallaştırmıştır.

Yeni tarihselcilik kuramı, tekil bir kültürden çıkan üst anlatılara karşı çıkarak ötekileştirilenler üzerinde durur. "Öteki” kavramı kimlik ve güç teorilerinde sıkça kullanılmaktadır. Bu kavram baskın gücün kendinden olmayan için belirlediği bir değerdir. Baskın gücün bir kimliği vardır. Bu kimlik sadece kendine benzer olanı tanımlar, kendinden olmayanı "öteki” ilan eder. "Öteki” ni oluşturan baskın güçtür. Yeni tarihselcilik bu güce karşı çıkarak, tarihte kendisine söz hakkı verilmeyenler ve kimliksizleştirilenler üzerinde durur.

Yeni tarihselcilikte "söylem" kavramı sıkça kullanılmaktadır. Söylem yeni tarihselciliğin Michel Foucault’ya borçlu olduğu bir kavramdır. Her zaman için iktidar ilişkilerine bağımlı olan söylem, insanları, nesneleri, bilgi ve soyut düşünce sistemlerini niteler, tanımlar ve sınıflandırır. Tyson'a göre söylem belirli bir zaman ve mekânda kültürel koşulların ve o dönemin otoritesinin yarattığı sosyal bir dildir. Tyson bu kavramı eserinde: "modern bilimler, liberal hümanizm, beyaz üstünlüğü, ekolojik duyarlılık, Hıristiyan köktenciliği” (2006:285) olarak örneklendirmiştir.

Söylem sözcüğü ideoloji sözcüğü ile yakın anlama sahiptir. Hatta bazen birbirinin yerine kullanılabilir. Bu kavram bir ideoloji aracı olarak dilin rolüne dikkat çeker. Farklı bir deyişle ideolojinin dile yansımasıdır.

Foucault'ya göre söylem, güçlü ve karmaşık yapılar bütünüdür. Bu yapılar iktidarın belirlemeleri sonucu şekillenir ve içerisinde güç unsurlarını barındırır. Çünkü güç her 
yerdedir; bir kurum, bir çatı, bir aidiyet değildir, aynı zamanda karmaşık, stratejik, hiyerarşik sistemde zirvede bulunan durumlara da verilen isimdir. Foucault'nun düşüncesine göre söylem toplumdaki bütün değerleri belirleyen bütün düşünce ve eylemlere şekil veren bir organizmadır.

Söylem aynı zamanda eksiklikleri olan bir düzendir. Foucault'ya göre bu eksiklikler ancak Nietzche'nin "geneology" (soykütüğü) yöntemine başvurularak anlaşllabilir. Bu yönteme göre her şeyin yapı sökümü yapılarak bunların özünde yatan güç ilişkilerine ulaşılabilir. Foucault'ya göre bunun en iyi yolu "marjinal", "farklı", "öteki" ilan edilmiş grupları incelemektir. Foucault "arkeolojik metot" olarak adlandırdığı bu yöntemde, tarihe tarihi olmayan bir yaklaşım sunmuştur. Foucault Nietzsche'nin yöntemi ile geçmişi eleştirel bir gözle sorgulamıştır.

Foucault'un Nietzche'den esinlenerek üzerinde durduğu soykütüksel yöntem aynı zamanda geleneksel tarihi çözümlemelere de karşı çıkar. Madan Sarup, Foucault'un tarih yazımına değinerek şöyle belirtir:

"Soykütüksel çözümleme bu yüzden tarihsel çözümlemenin geleneksel biçimlerinden çeşitli bakımlardan ayrlık gösterir. Sözgelimi geleneksel ya da 'bütüncül' tarih, olayları büyük açıklama dizgeleri ve çizgisel süreçler içerisine sokmak yoluyla önemli tarihsel anlara ve kişilere yönelip, bu amaçla tarihsel çalışmaya bir başlangıç noktası olabilecek belgeleri araştırırken; soykütüksel çözümleme tarihin göz ardı etmiş olduğu bir dizi görüngü eşliğinde, görülmeye değer olaylardan ayıklanarak dışlanan tek tek olaylara döner, onları canlandırmaya ve korumaya çalışır” (2004: 90).

Yeni tarihselciliğe göre küçük bir ülkenin diktatörü bile bütün gücü tek başına kullanmaz. Nitekim tanrının hiyerarşik düzeni emrettiği inanışını devam ettirmek için din söylemi, Darwine'nin en iyinin hayatta kalması teorisini destekleyebilmesi için bilim söylemi, moda dünyasının I. Lady Jacqueline Kennedy stilini kullandığı dönemde Nehru ceketlerinin moda olduğu gibi uygun kıyafetler giyinerek liderlerin popülaritesini sürdürebilmesi için moda söylemi, kural koyanların kurallarına karşı çıkmak için hukuk söylemi gibi egemenliğini sürdürebilmesi için gücünü farklı söylemlerde kullanması gerekir.

Geleneksel tarihin büyük bir özenle üzerinde durduğu savaşlar, kahramanlar ve liderler yerine, yeni tarihselci eleştirmenler daha sıradan ve günlük hayattan konular seçmiş, ezilenler, 1rksal meseleler, köle ticareti gibi geleneksel tarihin göz ardı ettiği olaylarla ilgilenmişlerdir, bunun yanı sıra, tarihi açığa çıkarma çabası neticesinde dikkatlerini kadınların dünyası, azınlıklar, deliler ve suçlular üzerinde yoğunlaştırmışlardır. Yeni tarihselcilik, tarihin ana karakterlerinin erkek ya da Avrupalı olduğunu ayrıca orta ya da üst sınıftan geldiğini ileri sürerek sadece geleneksel tarihi anlayışa değil aynı zamanda sınıflaşmaya da karşı çıkar. Nitekim sınıf, tarihi öznelleştiren bir oluşumdur. Mark Poster'ın da ileri sürdüğü gibi "Dünyada ortaya çıkan herhangi bir ideoloji veya teorisyenin pozisyonu, sinıf tarafindan belirlenir."(2006:25) Bu kuram aynı zamanda tarihin politik güçlerin elinde kaldığını düşünür ve bu eksende sorgulamalar yapar. Yeni tarihselcilik tarihte kadınların ezilenlerin ve köleler gibi alt sınıfların da var olduğunu 
vurgulamaktadır. $\mathrm{Bu}$ sebeple bir yaklaşım olarak yeni tarihselcilik bu konuları tarihin göz ardı ettiği detaylar çerçevesinde inceler.

Foucault'nun "sosyal ilişkiler, güç ilişkileridir" ilkesinin ardından Louis Montrose "Eliza, Queen of Shepheardes" başlıklı makalesinde Elizabeth dönemindeki pastoralleri sosyal ilişkiler boyutunda incelemiştir.

"Pastoral edebiyat türü, Kraliçe ve onun halkı için en doğru buluşma noktasıdır. Kraliçenin büyüklüğünü ve halkın güçsüz olduğunu göstermesi açısından onun ulaşılmaz olduğu ve lordlarına, köylülerine, saraydaki hizmetlilerine ve hemşerilerine karşı bilgili, sevimli ve sevecen olduğu hayalini beslemesi açısından... Bu tür pastoraller güç göstergesinin küçük başyapıtlarıydı" (1994:88-115).

Greenblatt Rönesans, Montrose Elizabeth dönemine odaklanarak bu dönemlerdeki güç ilişkilerini ortaya çıkarmaya çalışmışlardır. Güç ilişkileri her zaman tarihte var olmuştur. Bu ilişkiler marjinal grupları ortaya çıkarmış ve onları ötekileştirmiştir.

\section{Yeni tarihselcilikte tarih yazımı ve tarihçinin konumu}

Yeni tarihselcilik kuramı geçmişte yaşanmış olay ya da gerçeklerle değil, bu olayların nasıl yazıldığı ile ilgilenir. Bu durum yeni tarihselci düşünürlerin, geçmişte yaşanan olayların aktarılması konusunda yaşadıkları tereddütten kaynaklanmaktadır. Yeni tarihselciler, tarihin gerçekleri yansıtacak kadar nesnel olmadığını düşünürler. Brook Thomas'ın The New Historicism: And Other Old Fashioned Topics başlıklı eserinde dile getirdiği gibi, "bütün tarihi anlatılar politik oluşumlardır." (1991:5) Thomas ile aynı görüşe sahip Paul Hamilton Historicism başlıklı eserinde "tarih, insanların anlattığı öykülerden başka bir şey değildir" (2003:113) diyerek tarihe ve tarihçiye göndermeler yapar. Hem Brook hem de Hamilton tarihi sorgulamaya tabi tutarak onun sorunsallığını dile getirmeye çalışmışlardır. Onlara göre tarih, tarihçinin yaratıcılığına bağlı kurgusal bir üretimdir. Yeni tarihselcilik bu kurgusal oluşumu eleştiriye açık hale getirme amacına hizmet etmektedir.

"Başlangıçta tarih dediğimiz şey bir anlatıdan başka bir şey değildir. Her şey "hatıra eşyaları"nı okunmaları gereken bir biçimde düzenleyen bir efsanenin vitriniyle başlar. $\mathrm{Bu}$ efsane başka bir yerin tam burayı ve bu anı yineleyebilmesi için gereksinim duyduğumuz hayali boyutu sağlar. Yalnızca şimdiki zamanı ifade eden totolojik bir düzende alınan anlam dayatılır. Biz bu metni alınca, bir işlem zaten gerçekleştirilmiştir: bu metin yalnızca şimdiki zamanın bulmacasına kilitlenerek konan ve bütün bir toplumun aksamları şömine yanında anlattığ öykülere eklemlenen geçmişe ait parçaların varlığını sürdürmek için ötekiliği ve onun tehlikelerini ortadan kaldırmıştır. Bir efsane olarak düzenlenen bu işaretler, bununla birlikte, başka türlü de çözümlenebilir. İşte burada başka bir tarih başlar. Bu tarih heteronomiyi (yani “Olan biten bu”yu) dilin homojenliği ("Onların söylediği bu" ya da "Okuduğumuz bu") içinde kurmaya çalışır. Yani tarihsel boyutu bir metnin unsuru içerisinde üretir. Daha açık konuşmak gerekirse, bu eylem tarih yapmayla eştir."Tarih" sözcüğ $\ddot{u} i k i$ karşıt uç arasinda gidip gelir: anlatılan öykü (Histoire) ve üretilen masal” (Geschichte (1988:287-288). 
Tarihin kurgusallığına ve tarihçinin rolüne dikkat çeken Certeau, tarih için Almanca Geschichte yani masal sözcüğünü kulanmış, tarihin zihinsel tasarımlardan oluştuğuna dikkat çekmeye çalışmıştır. Certeau tarihçinin rolünün çok sınırlı olduğunu söyleyecek kadar da ileri gider:

"Tarihçi artık bir imparatorluğa biçim veren değildir. Dünya çapında bir tarih yazma hayalinin peşinde koşmamaktadır artık. Edinilmiş akıl yürütmelerin etrafında dolaşmaktadır. Kenarlarda çalışmaktadır. Bu nedenle tarihçi sinsice av peşinde dolasan biri haline gelir. Genelleyici özellikleri olan, güçlü merkezileştirici stratejilerle bezenmiş bir toplumda tarihçi zaten kullanılmış olan büyük bölgelerin sınırları doğrultusunda hareket eder" (1988:79).

Tarih olgusu, yeni tarihselcilerin eleştirel bakış açılarına, yeni yorumlara ve yeni düşünümsel yaklaşımlara açılım yapar. Bu açılımlar çoğunlukla Nietzsche'nin tarih felsefesine dayanır. Nietzscheci tarih, yeni tarihselcilik kuramında büyük önem taşır. Sarup, bu konuya değinerek şöyle belirtmektedir:

"Nietzscheci tarihçi şimdiyle başlar, belli bir ayrıma varana tek zamanda geriye doğru gider. Sonra ayrımın yarattığı dönüşümün izini sürerek tekrar ileriye doğru yönelir. Bu sırada bağlantılar kadar kopuklukları da korumaya özen gösterir” (2004:89).

Nietzsche'nin tarih felsefesi geçmişi metinsel olarak gösterirken tarihsel bağlamları da yeniden kurar. Yani geçmişte yaşanmış olayların varlığ konusunda tereddüt yaşamasa da bu olayların aktarımının kurgusallığına dikkat çeker. Onun tarih anlayışı şu sözleri ile netlik kazanmıştır:

"Tarihle her şeyden önce, etkin ve güçlü olan büyük bir savaşa girişip de örneklere, ustalara, avutucu ve öğüt vericilere, ermişlere gereksinim duyan, bunları çağdaşları ve arkadaşları arasında bulamayan kimse ilgilenir" (17:2005).

Nietzsche'nin bu sözleri bizi Certeau'nun 'masal' betimlemesine götürür. Aslında her .iki eleştirmen de aynı noktanın altını çizmektedir. Tarihin kurgusal boyutu, eleştirilerin merkezinde yerini alır. Böylece yeni tarihselcilik, anlatılarda tarihçinin konumunu sorunsallaştırmakla kalmaz aynı zamanda onun yazdıklarına da şüpheyle yaklaşır. Dolayısıyla tarih yazımını da sorunsal bir mercekle inceler. Serpil Oppermann tarih ve kurmaca arasındaki ilişkiye değinerek şöyle belirtir:

“Tarih yazımında geçmiş gerçekliğin yansıtılması önemli bir ontolojik sorundur. Yani tarihsel bilginin genel yaşam bağlantısı içinde doğru olarak konumlandırılması tartış1lır bir durumdur. Tarihsel bilginin doğruluk ölçütü, her zaman bilen öznenin yaratımına bağlı olduğu için, bilginin tarihle bağlantısının kurulması sorunsal bir durumdur. Aslında varlık düzeyinde geçmiş olaylar oldukları gibi var olmaktadır; ancak bunlara ilişkin bilgilerin doğrulukları ve yanlışlıkları metin düzeyinde kesinlikten uzaktır” (2006:7). 
Hayden White'a göre bir tarihçinin bakış açısı bir fizikçinin, biyologun ya da bir sanatçının bakış açısından daha farklıdır. White bu görüşünü şu sözleriyle ileri götürür:

"Tarihin, tarihsel bilgiyle bir araya getirilip karıştırıldıklarında tarihsel bilincin 'tarih felsefesinin' sapkınlıklarına düşmesine neden olan metafiziğin ya da dinin bir dalı olmadığını duyuran bildirge kısa sürede bir klişe haline gelmişti. Bunun yerine tarihin 'bilim' ile 'sanat'ın bileşimi olarak görülmesi gerektiği savunuluyordu. Ama 'bilim' ve 'sanat' terimlerinin anlamı net değildi. Tarihçinin belgeleri araştırırken ve geçmişte 'gerçekten olup bitenleri' belirlemeye gayret ederken 'bilimsel' olmaya çalışması ve geçmişi okurlarına 'sanatçı tarzıyla' sunması gerektiği kuşkusuz açıktı. Ama genel olarak tarihin, fizik ve kimya tarzında 'kesin' bir bilim olmadığı hususunda fikir birliği vard1" (2008:178).

White'a göre tarih bir bilim dalı olmadığı gibi, sadece metinselleştirilmiş anlatılardan oluşmuştur, bunun yanında tarihçi de bilim adamı kabul edilmez. Çünkü tarihi bilgiler deney yoluyla değil tahmin ve varsayımlarla edinilirler. Yani tarihsel bilgiler aktarılarak tarihçilerin eline ulaşır. Tarihçinin birinci elden ulaşabileceği tarihsel bilgi yoktur. Greenblatt bu konu ile ilgili düşüncelerini şu şekilde ifade etmektedir.

"Tarihsel deliller güvenilir değildir; toplumsal baskının yokluğunda bile, insanlar en içten inançları hakkında seve seve yalan söylerler. Utanmaz bir baskı ortamında kimbilir ne kadar daha yalan söylemişlerdir. Yine de burada politik sır saklayıştan belki de daha fazlası var" (2003:5).

Tarihçiler geçmişi anlatırken ve geçmişe göndermeler yaparken anlattıkları dönemi kendi düşüncelerine göre belli bir düzende yorumlarlar. Anlattıkları şeyleri inandırıcı kılmak için tarihsel bulguların ötesine geçerek genellemeler yaparlar. Farklı bir deyişle yazdıkları tarihsel dönemi yeniden kurgularlar. Louis Montrose bu olayı "Tarihin metinselliği ve metnin tarihselliğ̣i” (1989-15-36) biçiminde ifade etmiştir. Benzer görüşlere sahip Alun Munslow bu konuyu Tarihin Yapısökümü başlıklı eserinde şu şekilde dile getirmektedir: "Tarihi tarihçiler yazar; bu yüzden de tarihi, toplumun dişında objektif bir yöntem ya da yorum olarak değil, toplumun içinde kültürel bir ürün olarak ve tarihsel sürecin bir parçası olarak anlayabiliriz" (2000:25) ifadesiyle belirtmiştir. Munslow tarihi anlatıların kaçınılmaz olarak toplumsal ve kültürel zemine oturtularak incelenmesi gerektiğini savunur.

Yaşadıkları dönemin kültürleri bütün insanların görüşlerini etkilediği gibi tarihçilerin de görüşlerini etkilemiştir. Tyson, söz konusu eserinde tarihin nesnel olamayacağını şu sözleriyle belirtmiştir. "Tarihçiler objektif olduklarını düşünebilirler ancak neyin doğru, neyin yanlış; neyin uygar, neyin ilkel; neyin önemli, neyin önemsiz olduğu konusundaki görüşleri olayları yorumlama biçimlerini büyük ölçüde etkilemiştir.” (2006:283) Tyson bu görüşü ile toplumsal ve kültürel bağlamların hareketliliğinin tarihçiyi etkilemesini ve böylece tarih yazımında meydana gelen yorumlamaların kaçınılmazlığını anlatmaktadır. Yeni tarihselcilik, tarih yazımına yeni perspektifler kazandırarak tarihçinin rolünün 
sınırlı olduğunu vurgulamıştır. Dolayısıyla salt gerçeklik olarak kabul edilen yazılı tarih, yeni tarihselcilikle birlikte 'yanlı tarih' olarak değerlendirmeye tabi tutulmuştur. Böylece tarih yazımı, tarihi bir olayın yazınsal teorileştirilme süreci olarak adlandırılmıştır. $\mathrm{Bu}$ noktadan hareketle, tarihçinin rolü 'salt bir dizi öyküleştirme' hareketidir, çünkü bu kurama göre tarihsel gerçeklik göreceli bir olgudur.

\section{Yeni tarihselcilik ve edebiyat}

1970'li yılların sonu ve 1980'li yılların başında edebiyat eleştirmenleri, tarih ve edebiyat arasındaki ilişki ile daha çok ilgilenmeye başlamışlardır. "Yeni tarihselcilik, başlangıçta tarihçilerin ilgi alanı olarak değil, 1980'lerin başında ABD'de bir tür edebiyat eleştirisi olarak ortaya çıktı." (2000:54) Amerika'da ve İngiltere'de önemli edebiyat dergilerinin ve eleştirel kitapların gündeminde hep bu ilişki vardı. Feminist, Marksist ve postkolonyal kuramlar o dönemlerde çok önemli yaklaşımlar haline gelse de yeni tarihselci olarak bilinen bir grup eleştirmen Amerika'da bu akımın öncülüğünü yapmıştır. Bu eleştirmenlerin bakış açısına göre sosyal ve kültürel dokuyu yansıttığı sürece metinler politik oluşumlardan ve bu oluşumlara aracı olan bileşenlerden başka bir şey değildir.

Tarih salt gerçeklerden oluşan tutarlı bir sistem değildir; bunun aksine gerçeklerin tarihçinin gözündeki kırılma ve yansımalarıdır. Edebiyat, tarihi temsil eden bir araçtır. Kelley Griffith'in deyişiyle "Edebiyatın doğası tarihin doğası, tarihin doğası da edebiyatın doğasıdır." (2006:179). Yeni tarihselci eleştirmenlerin üzerinde durdukları nokta edebi metinleri yorumlarken kullandıkları tarihsel bağlamdır.

White'a göre tarihi anlatılar yazınsal kurallara bağlı olarak yazılırlar. Bu yönüyle tarih edebi bir metinden farksızdır. Bu anlamda tarihçi ve edebiyatçı arasındaki ayırımda bir belirsizlik vardır. Bu belirsizliğin sebebi Oppermann'ın sözleriyle açıklanabilir. “Tarih yazarı geçmişte olmuş olayları, roman yazarı hayalinde canlandırdığı olayları aynı yazınsal düzeni ve yazım yöntemlerini kullanarak yazar (2006:7).

Tarihe yönelik bu yeni bakış açısı aynı zamanda edebiyat ve edebiyat eleştirisine de yönelmiştir. Geleneksel edebi tarih anlayışına göre edebiyat eleştirisinin amacı tarihsel gerçekliği ortaya çıkarmak iken yeni tarihselci edebiyat eleştirisi farklı bir bakış açısı getirmiştir. Bu yeni sisteme göre tarih ancak edebiyat ile ve sübjektif yorumlamalar ile bilinebilir. Geçmişi anlamamız ancak bugünkü bilinç ile gerçekleşir.

Yeni tarihselcilere göre edebi metinler bir toplumdaki güç ilişkilerini yansıtmal1, okuyucuları o dönemde yaşanan olaylara inandırmalıdır. Bu sebeple olayları üçüncü kişi değil karakterler anlatmalı, karakterler konuşturulmalıdır.

Hem tarihi anlatılara hem de edebiyat incelemelerine yeni bir bakış açısı sunan yeni tarihselcilik, bazı kavramların da ortaya çıkmasına öncülük etmiştir. Bu kavramlar, kültür, metin, ideoloji, birey ve tarihten oluşmakta olup edebi çalışmalara yeni tarihselci yaklaşım sunmaktadır. Bu yaklaşım, tarihi anlatıları salt gerçeklerden uzak tutmaktadır. Bu kavramlardan en önemlisi, yani kültür, antropolojik anlamda belirli bir 
toplumun hayat tarzı, dili, ekonomisi, sanat1, dini gibi o toplumun kimliğini oluşturan unsurlar bütünüdür. Griffith'e göre "kültür bir toplumda herkesin paylaştığ1 kodlar bütünüdür.'(2006:180) Griffith'in bahsettiği kodlar sadece dili değil bir kültürün diğger bütün unsurlarını içinde barındırır.

Gösterge sistemleri ağı olarak kültür metinseldir. Geleneksel anlamda metin içerisinde sembolik bir sistemi barındıran yazılı bir belgedir. Griffith bu sembolik sistemleri "kelimeler, matematiksel semboller, imgeler, müziksel işaretler" (2006:180) olarak tanımlar. Postyapısalcılar bildiğimiz her şeyin dil ile elde edildiği görüşündedirler. Onlara göre her şey metindir. Derrida'nın da belirttiği gibi “Metnin dışında hiçbir şey yoktur (1997:158).

Yeni tarihselcilik, metnin üretildiği tarihi ve kültürel koşulların önemli olduğunu vurgulamaya çalışır. Metin ve tarihsel bağlam aynı derecede önemlidir. Çünkü metin ve bağlam birbirini tamamlayan öğelerdir. Bireysel kimlik ve toplum arasındaki dinamik etkileşim gibi edebi metinler de tarihsel olaylara şekil verirler ya da bu olaylar tarafindan şekillendirilirler.

İdeoloji bir grubun eylemlerini yöneten inançlar sistemidir. Neyin doğru neyin yanlış olduğuna bu sistem karar verir. İdeoloji aynı zamanda metinlerle temsil edilir. Yeni tarihselciler ideolojiyi politik anlamı ile değerlendirirler.

Yeni tarihselci eleştirmenlere göre edebiyat toplumsal üretimin bir parçasıdır. $\mathrm{Bu}$ sebeple edebi bir metin yazıldığı dönemin özelliklerini göstermeli, o dönem içerisindeki bütün ayrıntılara yer vermelidir. Yeni tarihselciliğin edebi eserlerde karşı çıktığı nokta, bu eserlerin gündelik hayatı yansıtmamasıdır. Bu yüzden yeni tarihselciler eserlerinde toplumsal yaşantıyı anlatacak en küçük ayrıntıya bile yer vermişlerdir. Böylece sosyal ve kültürel dokuyu yansıtacak kılık kıyafet, yaşam biçimi, inanç sistemi gibi unsurlar yeni tarihselci eserlerde çok fazla yer tutar.

Serpil Oppermann, yeni tarihselcilik kuramında dört kavramın öne çıktığını belirtmiştir. Oppermann'a göre bu kavramlar "metinsellik, metinler arası etkileşim, tarihsellik ve bağlamlamadır"(2006:1). Hayden White, Louis Montrose, Dominick LaCapra, Hans Kellner, Robert Berkhofer ve Louis O. Mink gibi yeni tarihselci düşünürler, tarihin metinselliği üzerinde durmaktadırlar. Bu düşünürler, tarihi bilgiye ulaşmanın tek yolunun yazılı metinler olduğunu ileri sürerler. Bu anlamda Louis Montose'un “metinlerin tarihselliği ve tarihin metinselliğgi” tanımı yeni tarihselci çalışmalarda önemli bir yere sahiptir. Montrose, bu tanımı ile tarihin belirli ve nesnel gerçeklerden oluşmadığını bunun aksine edebiyat ile karşılıklı etkileşim içinde olduğunu ve böylece edebiyat gibi yorumlanması gereken bir metin olduğunu belirterek hem anlamın hem de bağlamın metinsel özelliklerinin aynı derecede önemli olduğunu vurgulamaya çalışır. Jeremy Hawthorn, metinsellik ve tarihsellik arasındaki ilişkiyi titan ve gerilla savaşlarına benzetir. Hawthorn görüşünü şu ifadesi ile desteklemektedir:

"Edebi eserlerin metinsellik ve tarihselliği ile ilgili karmaşık ve çok yönlü düşünceler 1960 'ardan beri var olan teorik titanların savaşlarına benzemektedir. Bu savaşlar ge- 
rilla savaşlarına ve genç tanrılar arasındaki çatışmalara sebep olmuştur. Titanlar henüz ölmemiştir ancak onların gizli çarpışmaları küçük teorik anlaşmazlıklarda ifade ediliş tarzı bulmaktadır" (1996:8).

Theodore Roosevelt, "edebi eserlerdeki ilk unsur büyük bir hayal gücüdür" (2006:8) diyerek edebiyatın tanımını yapmıştır. Ancak daha sonra şöyle devam etmiştir: "Geçmişin aktarılması, ancak güçlü bir hayal dünyası olan bir kişi ile sağlanabilir" (2006:8). Roosevelt, tarihçinin hayal gücünden bahsederek onun edebiyatçı ile aynı olduğunu öne sürmüştür.

Yeni tarihselci yaklaşım, edebiyatı, belirli bir zaman ve mekânın kültürünü oluşturan yapıların, değerlerin, toplumsal kuralların ve söylemlerin bir parçası olarak görür. Farklı bir deyişle, yeni tarihselci bakış açısına göre edebiyat, politik, toplumsal, dinsel ve kültürel güç ilişkilerinin birbiri ile etkileşimi sonucunda oluşan bir sistemdir. Böylece yeni tarihselciler edebiyatın estetik boyutunu kaldırarak onu tarihle eşdeğer tutar. Munslow'un ileri sürdüğü gibi, “1990'lar ilerledikçe yeni tarihselcilik çok daha geniş bir analiz sahasına ilerleyerek edebiyat eleştirisinin sınırlarını aştı."(2000:54) Bu doğrultuda yeni tarihselciler tarih ve edebiyat arasındaki sınırları kaldırmışlardır. Tarihi anlatılara kuşku ile yaklaşmışlardır.

Munslow tarihin edebiyat ile olan ilişkisine değinerek şu soruları sorar:

- Tarihsel delillerin öz niteliği nedir ve ne işe yarar?

- Tarihçinin, toplum teorilerinden faydalanmasının ve tarihsel anlayışta açılklaylcl çerçeve kurmasının rolü nedir?

- Anlatı biçimi, tarihsel açıklama açısından ne kadar önemlidir? (2000:14).

Yeni tarihselci eleştirmenlere göre belirli bir zaman ve mekânda insanı tanımlayan edebi metinler aslında tarihin yorumlanmasıdır. Farklı bir deyişle, yazılı tarih bir edebiyat türüdür. Yeni tarihselcilik kuramına göre tarih bir bilim dalı değildir. Serpil Opperman'ın Postmodern Tarih Kuramı'nda bahsettiği gibi:

"Tarihin bilimsellik iddiası, tarihçinin olayları bir seçme süreci sonucu belli bir düzen içinde anlatıya çevirmesiyle zaten yıkılmaktadır. Yalnızca seçme ve ayıklama işleminin kendisi tarihin ne denli nesnellikten uzak olduğunu göstermektedir" (2006:8).

Oppermann bu görüşü ile tarihi bilimsel bir alan görmemektedir. Oppermann ile aynı doğrultuda düşünen M.C. Lemon'a göre: "Bir tarihçi olayları aktarırken sürekli seçme, anlam, önem ve objektiflik sorunları ile karşılaşır"(1995:133). Lemon, dile getirdiği bu düşüncesi ile tarihe olan güvensizliğine dikkat çekmektedir.

Hayden White yeni tarihselciliği "edebi çalı̧̧malara tarihi boyut kazandırmak için oluşturulan bir çaba" olarak tanımlamıştır. Hayden White'ın bu görüşünden yola çıkan Munslow'a göre: "Yeni tarihselcilik edebi eserleri tarihsel bağlamları ile ilişkilendirmektir. Şiirler, romanlar, oyunlar sadece birbirleri ile olan yapısal ilişkilerle değil aynı zamanda sosyal kurumlarla ve tarihi olaylarla olan çağrışımsal ilişkilerle de ele alınmalidir" (2000:31). 
Yeni tarihselcilik temelde eski tarihsel anlayışa karşı çıkarak tarihsel anlatılarda meydana gelen süreksizliklerden bahseder. Yeni tarihsel özellikler taşıyan bir roman anekdotla başlayabilir. Edebiyat tarihçisi Vincent Leitch The Norton Anthology: Theory and Criticism başl1klı eserinde Greenblatt'ın görüşüne yer vermiş ve görüşlerini şöyle aktarmıştır. "Greenblatt'a göre edebi eserler güçlerin çatıştığı aynı zamanda durmaksızın değişen kişisel çıkarların söz konusu olduğu alanlardır ve daima devrilme ya da yıkılma hissi uyandıran durumlardan oluşmaktadırlar" (2001:2250).

Yeni tarihselci edebiyat eleştirisi geleneksel edebiyat eleştirisinden ayrıllır. Yeni tarihselci eleştiri, yazarın hayatı üzerinde durur, çünkü yazarın hayatı yazdığı eser için büyük bir önem taşır. Geleneksel tarihçilere göre edebiyat, nesnel ve fark edilebilir gerçeklerden oluşan tarihten farklı olarak öznel bir alanda bulunur. Böylece edebiyat tarihin izin vermediği hiçbir şeyi yorumlayamaz. Diğer bir deyişle tarih edebiyattan çok farkl1dır, aynı zamanda daha önemlidir.

Metin ve bağlam arasındaki karmaşık ve çelişik ilişkiye bağlı olarak tarih ve kurgu arasındaki sınırla ilgili uzun süren bir tartışma söz konusudur. Chung Hsiung Lai bu ilişkiyi bir sarkaca benzetmektedir. Greenblatt, "New Historicism and a Feminist Genealogy" adlı makalesinde bu konuyu şöyle dile getirir:

"Edebiyat teorisi tarihi, bir anlamda metinsellik ve bağlamsallık arasında gidip gelen, bir sarkaç gibi sallanan ve anlık zaferlerle birinin diğerine üstünlügü ile sonuçlanan, metinselliğin sözel edebiyat üzerindeki üstünlüğü ve bağlamsallığın sosyo tarihsel üstünlüğü arasındaki gidiş gelişi yansıtan teorik savaşlar serisidir” (2006:2).

Metin ve bağlam ilişkisine değinen Hawthorn, metni zaman ve mekândan bağımsız ancak bağlamdan ayrılmaz bir bütün olarak tanımlamaya çalışır. Bu ilişkiye bir örnekle değinerek şöyle belirtir: "Eşime yazdığım bir mektup on yıl sonra da başkaları tarafindan okunabilir, bu metin zaman ve mekândan bağımsız olsa da belirli bir bağlamda değerlendirilmelidir"(1996:11). Hawthorn bu görüşünü Shakespeare'ın eserleri ile örneklendirir. Yüzyıllar önce yazılmasına rağmen Shakespeare'ın eserlerinin günümüzde hala okunması bu eserlerin bağlamsal yapısı ile ilgilidir.

1970'leren sonra tarihsel ve edebi çalışmalar Chung Hsiung Lai'nin bahsettiği sarkacın farklı iki yanında kalmamıştır. Bunun aksine metin ve bağlam, tarih ve kurgu arasındaki sınırlar kalkmıştır. Farklı bir deyişle, postmodern dönemde tarih edebi tasarımlar ve güç ilişkileri ile kurulan bir söylem haline gelmiştir. Bu anlamda tarih ideolojik ve öznel bulunmuştur.

Yeni tarihselciler hem geleneksel tarihin edebiyatı marjinalleştirmesine hem de yeni eleştirinin edebi metinleri tarihin ötesinde kutsal bir yere koymasına karşı çıkarlar. Yeni tarihselciler, geleneksel edebiyat düşünürlerinin aksine, edebi bir metnin, yazarın niyetini tam anlamıyla içerisinde barındıramayacağını düşünürler. Aynı zamanda yeni eleştiricilerin aksine, edebi metinlerin yazıldıkları zaman ve mekânda bu dönemleri objektif bir biçimde yansıtmadıklarını düşünürler. Bu eleştirmenlere göre edebi metinler yazıldıkları 
dönemin kültürünün baskınlığı sonucu kaçınılmaz bir şekilde oluşan kurgulardır.

Yeni tarihselcilik kuramında iki eser çok önemlidir. Bu romanlar Joseph Conrad'ın Karanlı̆̆ın Yüreği, Toni Morrison'ın Sevilen başlıklı eserleridir. Conrad, eserinde Avrupa'nın Afrika'yı ticari olarak sömürmesi anlatılır ve içinde bulunduğu toplumun o dönemdeki koşullarını objektif bir şekilde yazar. Morrison'ın eserinde, bir grup köle savaştan önce Ohio'da yaşanan acı gerçeklerden ve hafızalarını işgal eden anılarından kurtulmaya çalışır.

Geleneksel tarihi eleştiriye göre bu iki romanın doğruluğu tarihsel belgelerle karşılaştırılarak ölçülebilir. Yeni tarihselci yaklaşıma göre hem Karanlı̆̆ın Yürĕgi hem de Sevilen içindeki karakterlerin yaşadıkları dönemi yorumlamalarını içerir. Bu karakterlerden yola çıkarak Joseph Conrad ve Toni Morrison'ın bu romanları yazdığı dönemlerde, insanların yaşadığı olaylar anlaşılabilir.

Karanlığın Yüreği, geleneksel tarihçilere göre on dokuzuncu yüzyılda Avrupa'nın Congo'daki eylemlerini anlatan ve bu anlatıları tarihsel kayıtlara dayandiran bir eserdir. Aynı şekilde geleneksel bir tarihçi Sevilen'i on dokuzuncu yüzyıldaki tarihsel kayıtlarla inceler. Geleneksel tarihçilerin aksine yeni tarihselciler Conrad'ın eserini daha farklı biçimde incelerler. Onlara göre Conrad bu eseri yazdığg dönemde yaşadığg toplumda mevcut olan iki söylem kullanmıştır: anti kolonyalizm ve Avrupa merkezcilik. Romandaki anti kolonyalist tema Avrupa'nın Afrikalılar üzerinde üstünlük kurması ve onları sömürmesidir.

Yeni tarihselci bir eleştirmenin bir metni yorumlarken sorduğu sorular şunlardır:

- Metinde öne çıkan güç ilişkileri nelerdir?

- Açık ya da gizli gücü yöneten kimdir?

- Gücün kullanılmasını tehdit eden şey ne olabilir?

- Gücü elinde bulunduran kişiler bu gücü yıkmaya mı çalışıyor?

- Tarihi ve kültürel olaylar metni nasl etkileyebilir?

- Bu eser yazıldı̆̆ dönemdeki kültürde dil, bilgi ve güç arasındaki ilişkide neyi açı̆̆a çıkarır?

- Bu eser nasıl bir insan karakteri ve nasıl bir insan vücudu imgesi belirtir ya da oluşturur?

- Bu eser nasıl bir gerçek ve güç modeli yaratır?

Yeni tarihselcilik edebi tarih ve kültürel çalışmalarda postmodern tarih olarak da adlandırılabilmektedir. Nitekim 'türlerin yıkılışı' yaklaşımını getirir. Sürekliliğe karşı çıkarak süreksizliklere yer verir. Geleneksel tarih anlayışını yıkmak için birbirinden bağımsiz anekdotlar verilir.

Yeni tarihselcilik akımında dil önemli bir konudur. Lacan’ın deyişiyle “bizi özne k1lan dilin kendisidir" (Sarup, 2004:16). Dil, kimlikle ilgilidir çünkü biz ancak dil aracılığı ile kendimizi anlatıp başkaları ile iletişim kurabiliriz. Yeni tarihselciler Levi- Strauss'un kültür ve dil konusundaki görüşlerinden etkilenmişlerdir. Mark Poster, Foucault ve LeviStrauss'un görüşlerine yer vererek şöyle belirtir: 
“Levi-Strauss'un akrabalık çalışmasında gördüğümüz gibi, içsel mekanizmaları, toplumsal analiz için bir model olarak hizmet edebilecek bilimsel bir paradigma olan masum bir dil yoktu. Foucault'a göre söylem olarak düzenlenen dil, insan topluluklarını etkileyen ve nihayetinde söylemin oluşumunu yeniden düzenleyen disiplin biçimleriyle her zaman ilişsiliydi. Hakikat ve iktidar; teori ve pratik arasındaki etkileşime dair ince ama iyi tanımlanmamış bu kavrayış, Foucault'un araştırmalarının ana teması olmuştur" (2006:24).

Strauss'a göre dil kendi kendini yöneten bir sistemdir. Bu noktada güç dil ile yansitılır. Greenblatt dili özellikle İngiliz Rönesans döneminde büyük bir güç olarak görür. Greenblatt'a göre dil göndergeden ayrılmıştır. Karakterler her ne kadar bu boşluğu sözlerle doldurmaya çalışsalar da bunu başaramazlar. Greenblatt'a göre büyük sözler konuşulmuş ve bir boşluğun içinde kaybolmuştur.

“Ölülerle konuşma arzusuyla başliyorum”diyen Greenblatt geleneksel anlamda sözlü dilin yazılı dile ola baskınlığını anlatır. Sözlü dilde belirsizlikler daha azdır. Renaissance Self-Fashioning başlıklı eserinde dil ve güç kavramlarını tartışır. Ona göre bir toplumdaki güç politikasını yöneten bireydir.

\section{Sonuç}

Yeni tarihselcilik edebiyata sunulan tarihi yaklaşımları reddeten yeni eleştiri kuramına karşı çıkarak tarih ve edebiyat ilişkisi üzerinde durur. Bu iki disiplini ayıran kesin çizgiler bulunmadığına dikkat çeken yaklaşım, tarihin edebiyat boyutunu, edebiyatın da tarihi boyutunu ele alarak Montrose'un deyişiyle, tarihin metinselliği, metnin de tarihselliği üzerinde durur.

Yeni tarihselcilik, öncelikle metin incelemelerini irdeleyerek bağlam kavramını ön plana çıkarır ve bir metnin ancak bağlamla değerlendirilebileceğini gündeme taşır. $\mathrm{Bu}$ noktada postyapısalcılıktan yararlanır. Hem post yapısalcılıkta hem de yeni tarihselcilikte öne çıkan en büyük unsur olan dil, Roland Barthes ve Derrida gibi düşünürlerle önem kazanır. Bu düşünürlere göre bir metinde birden fazla gösterge vardır. Bağlam ancak bu göstergelerle birlikte ele alınabilmektedir. Sözcükler, metin içerisinde pek çok anlamı barındırır.

Yeni tarihselcilik kuramında edebiyat, birden fazla bilinçle kurgulanan sosyal ve kültürel bir oluşumdur, bu yüzden tek bir bilinç düzeyine indirgenemez. Bu yüzden edebi bir metni analiz etmek için en iyi yöntem o metne üretildiği kültürel koşulların çerçevesinden bakmakla elde edilir. Edebiyat tarihin sınırlı bir yansımasıdır. İnsanın kendisi sosyal bir oluşumdur. Tarih, zaman ve insan arasında meydana gelen kırılmalardır. Edebiyat eleştirmeni sadece kendi kültürel oluşumu doğrultusunda yazabilir. Bu yüzden edebiyat eleştirisi ancak eleştirilen eserin kültürel koşullarının göz önünde bulundurulması ile gerçekleşir. 


\section{Kaynaklar}

Brook, T. (1991) The new historicism: and other old fashioned topics, Princeton: Princeton University.

Certeau, M. (1988) The writing of history, (Çev. Tom Conley), New York: Columbia University.

Chung-Hsiung, Lai. (2006) Greenblatt, new historicism and a feminist genealogy. Intergrams, 7(1). 2.

Derrida, J. (1997) Of Grammatology, (Çev. G. C. Spivak), John Hopkins Maryland: University.

Greenblatt, S. (2003) Shakespeare ve kültür birikimi, (Çev. N. Pelit), Ankara: Dost. Hamilton, P. (2003) Historicism, New York: Routledge.

Hawthorn, J. (1996) Cunning passages: New historicism, cultural materialism and Marxism in the contemporary literary Debate, London: Arnold.

Kelley, G. (2006) Writing essays about literature: A Guide and style sheet, Canada: Thomson Wadsworth.

Lemon, M.C. (1995) The discipline of history and the history of thought, London: Routledge.

Montrose, L. (1994) Eliza, Queen of Shepheards, London: Routledge. (1989) Professing the renaissance: The Poetics and politics of culture, London: Routledge.

Munslow, A. (2000) Tarihin yapısökümü, (Çev. A. Yılmaz), İstanbul: Ayrıntı.

Nietzsche, F. (2005) Tarihin yaşam için yararı ve yararsızllğı üzerine, İstanbul: Say Oppermann, S. (2006) Postmodern tarih kuramı, Ankara: Phoenix.

Poster, M. (2006) Foucault, marksizm ve tarih, (Çev. F. Güder), İstanbul: Otonom. Sarup, M. (2004) Postyapısalcıllk ve postmodernizm, (Çev. A. Güçlü), Bilim ve Ankara, Sanat.

Theodore, R. (2006) History as literature and other essays, New York: Cosimo. Tyson, L. (2006) Critical theory today: a user friendly guide, New York: Routledge.

Vincent B., L. (2001) The norton anthology, theory and criticism, New York: Norton\&Company.

White, H. (2008) Metatarih, (Çev. M. Küçük), Ankara: Dost. 